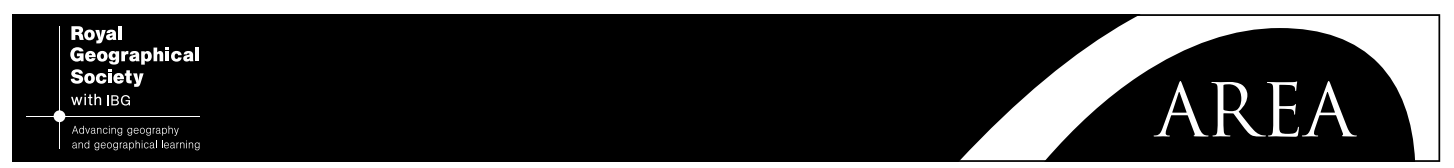

\title{
Confluences of human and physical geography research on the outdoors: an introduction to the special section on 'Exploring the outdoors'
}

\author{
Pauline Couper* and Richard Yarwood** \\ *University College Plymouth St Mark \& St John, Plymouth PL6 8BH \\ Email: pcouper@marjon.ac.uk \\ **School of Geography, Earth and Environmental Sciences, Plymouth University, Plymouth PL4 8AA
}

Revised manuscript received 18 August 2011

\begin{abstract}
This special section of Area demonstrates the multiple ways that geographers engage with the outdoors. Human and physical geographers have pursued different paths of academic research on the outdoors, ranging from 'objective' empirical epistemologies to understandings of outdoor spaces as socially constructed. The special section highlights that more-than-representational accounts and more-thanscientific encounters have the potential to bridge human and physical geographies and lead to new understandings of the outdoors. In this editorial overview we argue for the outdoors as a site of boundary crossing between human and physical, and between 'academic' and 'explorer', geographies.
\end{abstract}

Key words: outdoors, fieldwork, human geography, physical geography, exploration, affective

\section{Background}

Geography's historical connection with adventure and exploration is well documented (e.g. Livingstone 1992; Unwin 1992; Gregory 2000; Johnston and Sidaway 2004; Nayak and Jeffrey 2011), but waned as geography established itself as a University discipline. It could be said that, particularly during the twentieth century, geography and exploration went their separate ways: geography into academia, and exploration into 'outdoor adventure' and recreation. ${ }^{1}$ Such changes are reflected in the histories of geographical institutions such as the Royal Geographical Society, from its inception in 1830 and strong association with explorers of the day, through the 'break-off' creation of the Institution of British Geographers as a learned society in 1933, the re-merger of the two in 1995, and the remaining tensions that have most recently surfaced in debates about the Society's use of its funds (Maddrell 2010).

The most immediate connection between geography and exploration, and arguably a legacy of this history, is fieldwork. Notwithstanding critiques (such as that by Katz 1994), 'outdoor' fieldwork continues to feature prominently in research and is often an attraction for undergraduates choosing to study the subject at university
(Trudgill 2003; Fuller 2012). In physical geography, the philosophical primacy of empirical investigation has lent fieldwork a special status: hence the oft-cited observation of Richard Chorley, 'whenever anyone mentions theory to a geomorphologist, he instinctively reaches for his soil auger' $(1978,1)$. Yet it is apparent that fieldwork also engages physical geographers with the environment in a more-than-scientific way (Boyle et al. 2003; Maskall and Stokes 2008; Fuller 2012). Thus Neil Roberts looks forward to fieldwork because

physical geographers are fortunate indeed, because not only do we share the excitement of science, but we also enjoy the aesthetic pleasures that can come from working in the field. Lack of sleep and damp boots notwithstanding, few scientists experience a desert sunrise, the scent of aromatic herbs, or flamingos rising from an East African salt lake as part of their studies. $(1992,20)$

Phillips $(1999,759)$ recognises the role of 'experience, intuition, tacit knowledge and other deeply individual ways of knowing' in geomorphological research, yet still this falls short of explicit consideration of fieldwork as an embodied experience and the influence this experience may or may not have on the processes of primary data 
collection and interpretation. Bracken and Mawdsley (2004) have examined the embodied experience of fieldwork, but in the context of females' participation in the cultures of physical geography, rather than in relation to its epistemological implications. Raab and Frodeman's (2002) 'phenomenology of geology' is applicable here, but that work is confined to a focus on field observation, leaving equipment-laden quantitative field research uncharted territory. Raising the issue of the practicalities of fieldwork then begs consideration of the role of 'everyday' geographical knowledge in research: the ability to read a map and navigate oneself to a field site, perhaps, or the choice of route to take when traversing the difficult terrain of a field site. Cosgrove and della Dora argue that 'the human connection with high places is a two-way physical and imaginative dialogue in which geographical knowledge is continuously built and destabilised, shaped and reshaped' $(2009,4)$. Indeed, Keith Richards argues that the addition of post-modernist approaches to the traditions of physical geography may lead to a recognition that 'perception reflects the perspective of the observer' and the case that a 'simplistic, positivist tradition is almost completely irrelevant' (2009, 43). Although many research seminars in physical geography include comments about the fun or hardships of working in the field and pictures of geographers getting muddy when coring, wet when sampling a river or baked when working in a desert, these experiences of the outdoors often remain hidden in the final writing of such research (Viles 2003).

By contrast, many human geographers and social scientists have attempted to theorise these bodily, emotional and affective engagements with the outdoor landscapes (Edensor 2000; Ingold 2000; Wylie 2005) and how these are mediated by political, structural and more-than representational factors (Blacksell 2005; Sidaway 2009) as well as geological and geomorphological processes (Massey 2005). Yet many 'outdoor' spaces, such as mountains, moors, glacial and periglacial areas, rivers, bogs, swamps, the sea and the other 'wild' terrains, remain largely the preserve of physical geographers, intent on mainly understanding the processes that shape and form them. As Geoff Wilson (2012) notes, human geographers are rarely found in such localities, being content to 'talk the talk' rather than 'walk the walk' (or climb the ropes, descend into holes, cross rivers, paraglide over valleys etc.). The popularity of television programmes presented by geographers such as lain Stewart, Nick Middleton or Nicholas Crane show that there is some public appetite to see geographers engaging with the outdoors in both scientific and adventurous ways.

We call, therefore, for a confluence of research by human and physical geographers. This should not be a return to a paradigm of exploration and adventure or regional, topographic description, but there is scope for human and physical geographers to draw upon on each other's work to recognise how one influences the other. The aim of this special section is to demonstrate the multiple modes of current engagement of geographers with the outdoors and practices of exploration.

\section{Exploring the outdoors: the special section}

This special section draws together papers to begin addressing this task. Many are taken from a session in the 2009 RGS Annual Conference Session on 'The Great Outdoors' (see also Eden and Barratt 2010) that attempted to draw together human and physical practices in outdoor research in three ways:

1 how the performance of fieldwork in the outdoors informs knowledge and methodological practices in human and physical geography

2 the relational and hybrid positioning and identities of geographers as explorers and/or academics

3 how perspectives from human and physical geographies can mutually inform understanding of the outdoors.

The papers in the special section together present a range of methodological approaches to understanding the outdoors and our engagements with the outdoors, including textual analysis, interviews, video analysis, ethnography and reflective accounts. However, we begin and end with what is perhaps seen as the 'traditional' connection between geography and the outdoors: fieldwork.

Ian Fuller's (2012) paper, in which he reflects on his experiences of teaching in the field in various locations in Europe and New Zealand, provides an apt starting point for the special section. Fieldwork has long been seen as a staple part of geographical education (Sauer 1956), but varies considerably in its delivery and pedagogic value. Fuller notes the importance of working 'outside the bus' in a range of environments from the distant and exotic to the local and more every-day. Using quotes from student evaluations, he notes that outdoor working offers an often intangible experience that has many pedagogic benefits. He argues that fieldwork is an important part of undergraduate teaching, and that the outdoors presents a 'high place' for learning in more ways than one.

Geoff Wilson (2012) continues this theme of 'high places', but by contrast draws attention to places that are rarely visited by geographers: extreme mountain environments above $8000 \mathrm{~m}$ altitude. He argues that, given the dangers and challenges posed by mountaineering in these places, geographical 'researchers may never be able to fully unravel the intricacies of socially constructed and 
physical thresholds'. Wilson consequently draws upon climbing literature to examine how these outdoor spaces have been socially constructed by climbers (from the first world) and how these constructions have influenced, and been influenced by, various climbing expeditions.

Whereas Wilson discusses the representation of mountains, Paul Barratt's (2012) article takes a morethan-representational approach to understanding mountaineering. Drawing on interviews with rock and ice climbers, he examines how the practices of climbing can be thought of as assemblages between people, nature and, crucially, technologies (see the recent special section on 'assemblage' in Area volume 43, issue 3). He stresses the 'psychological protection' offered by particular pieces of equipment (as well as mascots) to climbers. Close bonds are established with favourite items to the extent that climbers develop symbolic and symbiotic relationship with 'material others'. As well as establishing the nature of these assemblages, Barratt also reveals how they are maintained. In this case, he points to a 'pet-like' relationship with kit that ensures mutual protection and companionship.

Pets of a more traditional nature are discussed by Katrina Brown and Rachel Dilley (2012) who also focus on 'more than human' relationships with the outdoors. Their paper examines how people and dogs respond to guidelines laid out by the Scottish Outdoor Access Code (a set of guidelines aimed at encouraging good conduct in rural areas). It traces some of the human and non-human practices that enable dog-walking to become interwoven with other traces of nature and the outdoors. Given the more-than representational nature of these interactions, their research paper draws upon video analysis to examine these relationships.

The final two papers attempt to draw some of these themes together. First, Richard Yarwood (2012) recounts a night spent training with Dartmoor Rescue Group. In doing so he seeks to resolve some of the tensions between accounts that explore emotional or affective engagement with the outdoors and those more applied geographies that engage with the policies, politics and structures that shape these places and encounters. Although originally part of a research project, these (enjoyable) field experiences prompted the author to join the Dartmoor Rescue team. Thus, instead of participatory research, research prompted participation, highlighting the blurring between academic work, personal knowledge and experience in understanding the outdoors.

In our final paper, Pauline Couper and Louise Ansell (2012) draw attention to the role of embodied experience in the framing and execution of a field research project. Moving beyond traditional concerns with physical geography, they note how the materiality of the field site and their bodily engagements with it not only influence field- work practice but have a bearing on the knowledge that it produces. Demeritt (1996) argues that paying attention to the practices by which scientific representations of the world are produced holds potential to lead to a much greater understanding of science than simply focusing on the representations themselves. Similarly, Shapin identifies that historians of science have become increasingly interested in scientific practice and scientists' bodies: 'we now want to know about the sharpness of astronomers' vision, the dexterity of experimentalists' hands, the acuity of chemists' olfactory sense' $(2010,9)$. Developing such avenues focused on field research, furthering understanding of the epistemological function of embodied field experiences in geography, arguably holds potential to improve field research practice.

The on-going project on which Couper and Ansell's paper is based seeks to apply fluvial geomorphology to outdoor recreation practices, specifically river crossings by hillwalkers. This follows Sakals et al.'s (2010) application of geomorphology and ecology to understand the risk of bear attack to wilderness campers in southwestern Yukon, Canada. Together these perhaps indicate that physical geographers' engagement with outdoor recreation is beginning to move beyond the science of 'recreation ecology', with its emphasis on revealing the environmental impacts of outdoor recreational activities. Understanding such impacts is undoubtedly important, but physical geographers also have potential to inform outdoor recreational practices in other ways; a potential dependent on the professional engagement of geographers with the discourses of, and problems defined by, the outdoor recreation community. Couper and Ansell conclude the special section by arguing that an 'unsettled frontier' (Driver 2001) between science and adventure will continue to have important consequences for geographical understandings of the outdoors.

\section{Conclusions}

In recent years, the 'outdoors' has rapidly gained a foothold as an international field of academic study in its own right, with the establishment of dedicated scholarly journals and an increasing availability of graduate and postgraduate degree awards in outdoor education, outdoor adventure, outdoor learning and outdoor recreation. These degrees may incorporate some geography in some institutions, but they are equally (and probably more) likely to draw on psychology, educational theory, sociology, sport, management and marketing, with psychology and educational theory dominating literature in the outdoor journals. The RGS conference session demonstrated that geography and geographers could be making a vibrant contribution to this rapidly developing area of teaching and research, and we hope that this special 
section of Area illustrates this potential to a larger audience. Together these papers demonstrate some of the multitude of ways in which geographers know outdoor environments, develop knowledge through being outdoors, and are developing knowledges of engagements with the outdoors.

The special section undoubtedly has limitations: it remains predominantly Anglo-centric, although the contributions of Fuller, Barratt and Wilson do extend beyond the UK; and it remains predominantly land-based in its consideration of outdoor spaces. ${ }^{2}$ Notwithstanding these restrictions, the collection begins to hint at ways in which some of the institutionally constructed boundaries between human and physical geographer as well as between academic and explorer - could be crossed to provide new insights into the outdoors. Physical geographers in the field have much to learn from human geographers' understandings of embodied experience, practice and performance. Recreational ecologists might benefit from understanding the role of outdoor recreation in sustaining the political will, and hence financial means, to protect the very wilderness areas that are vulnerable to damage by recreation. Outdoor practitioners may profit from physical geographers' understanding of the natural environments they work in. ${ }^{3}$ Human geographers' insights into the ways in which outdoor geographical knowledges are enacted can shed new light on the workings of the policies and codes through which engagements with the outdoors are managed. As this special section has highlighted, there are a wide range of methods that can be employed by human and physical geographers to make these connections.

Clearly we are not arguing for a return to the explorergeographer, nor do we argue that all research should be done outdoors (indeed the study of indoor leisure is much neglected; Yarwood and Shaw 2010). We do, though, note that for some geographers engagement with the outdoors through leisure practices has inspired research (Barratt 2012; Fuller 2012; Wilson 2012) and vice versa (Yarwood 2012). It should be recognised that knowledge of the outdoors draws not only upon academic understanding, but on a hybrid mix of the experiential and personal too. It seems there is much scope for human and physical geographers to work together and with those beyond the discipline, to the benefit of geography, outdoor practitioners and those who manage outdoor environments.

\section{Notes}

1 These two areas are not, of course, mutually exclusive as Wylie (2008) demonstrates by weaving together an account of Scott's polar expeditions and his own archival research.

2 The sea is an obvious omission and was one of the RGS's annual conference themes in 2010.
3 For example, water awareness training for the rescue services is based on an understanding of hydrology (HM Fire Service Inspectorate 2002) and should therefore continue to be updated to reflect advances in hydrological knowledge.

\section{References}

Barratt P 2012 'My magic cam': a more than representational account of the hybrid climbing assemblage Area 44 46-53

Blacksell M 2005 A walk on the South West Coast Path: a view from the other side Transactions of the Institute of British Geographers 30 518-20

Boyle A, Conchie S, Maguire S, Martin A, Milsom C, Nash R, Rawlinson S, Turner A and Wurthmann S 2003 Fieldwork is good? The student experience of field courses Planet Special Edition 5 48-51

Bracken L J and Mawdsley E 2004 'Muddy glee': rounding out the picture of women and physical geography fieldwork Area 36 280-6

Brown K and Dilley R 2012 Ways of knowing for 'response-able' more-than-human encounters: the role of anticipatory knowledges in outdoor access Area 44 37-45

Chorley R J 1978 Bases for theory in geomorphology in Embleton C, Brunsden D and Jones D K C eds Geomorphology: present problems and future prospects Oxford University Press, Oxford $1-13$

Cosgrove D and della Dora V 2009 Introduction: High Places in Cosgrove D and della Dora V eds Highplaces: cultural geographies of mountains, Ice and science IB Tauris, London $1-16$

Couper P and Ansell L 2012 Researching the outdoors: exploring the unsettled frontier between science and adventure Area 44 14-21

Demeritt D 1996 Social theory and the reconstruction of science and geography Transactions of the Institute of British Geographers 21 484-503

Driver F 2001 Geography militant: cultures of exploration and empire Blackwell, Oxford

Eden S and Barratt P 2010 Outdoors versus indoors? Angling ponds, climbing walls and changing expectations of environmental leisure Area 42 487-93

Edensor T 2000 Walking in the British countryside: reflexivity, embodied practices and ways to escape Body and Society 2000 81-106

Fuller I 2012 Taking students outdoors to learn in high places Area 44 7-13

Gregory K J 2000 The changing nature of physical geography Arnold, London

HM Fire Inspectorate 2002 Safe working near, on or in water. Fire and rescue service manual - volume 2: fire service operations The Stationery Office, London

Ingold T 2000 The perception of the environment Routledge, London

Johnston R and Sidaway J 2004 Geography and geographers: Anglo-American human geography since 1945 6th edn Arnold, London

Katz C 1994 Playing the field: questions of fieldwork in geography Professional Geographer 46 67-72 
Livingstone D N 1992 The geographical tradition Blackwell, Oxford

Maddrell A 2010 Academic geography as terra incognita: lessons from the 'expedition debate' and another border to cross Transactions of the Institute of British Geographers 35 149-53

Maskall J and Stokes A 2008 Designing effective fieldwork for the environmental and natural sciences The Higher Education Academy Subject Centre for Geography, Earth and Environmental Sciences, Plymouth

Massey D 2005 For space Sage, London

Nayak A and Jeffrey A 2011 Geographical thought: an introduction to ideas in human geography Prentice Hall, Harlow

Phillips J D 1999 Methodology, scale, and the field of dreams Annals of the Association of American Geographers 89 754-71

Raab T and Frodeman R 2002 What is it like to be a geologist? A phenomenology of geology and its epistemological implications Philosophy and Geography 5 69-81

Richards K 2009 Geography and the physical sciences tradition in Clifford N, Holloway S, Rice $\mathbf{S}$ and Valentine G eds Key concepts in geography Sage, London 21-45

Roberts N 1992 Not so remote sensing of our environment in Rogers A, Viles $\mathbf{H}$ and Goudie A eds The student's companion to geography Blackwell, Oxford 19-21

Sakals M, Wilford D, Wellwood D and MacDougall S 2010 Active fans and grizzly bears: reducing risks for wilderness campers Geomorphology 115 305-14

Sauer C O 1956 The education of a geographer Annals of the Association of American Geographers 46 287-99

Shapin S 2010 Lowering the tone in the history of science: a noble calling in Shapin S Never pure: historical studies of science as if it was produced by people with bodies, situated in time, space, culture, and society, and struggling for credibility and authority The Johns Hopkins University Press, Baltimore MD $1-14$

Sidaway J 2009 Shadows on the path: negotiating geopolitics on an urban section of Britain's South West Coast Path Environment and Planning D: Society and Space 27 1091-16

Trudgill S 2003 Meaning, knowledge, constructs and fieldwork in physical geography in Trudgill S and Roy A eds Contemporary meanings in physical geography: from what to why? Arnold, London 25-46

Unwin T 1992 The place of geography Longman Scientific and Technical, Harlow

Viles H 2003 'The writing's on the walls': on style, substance and selling physical geography in Trudgill S and Roy A eds Contemporary meanings in physical geography Edward Arnold, London 261-8

Wilson G 2012 Climbers' narratives of mountain spaces above 8000 m: a social constructivist perspective Area 44 29-36

Wylie J 2005 A single day's walking: narrating self and landscape on the South West Coast Path Transactions of the Institute of British Geographers 30 234-47

Wylie J 2008 The ends of the earth: narrating Scott, Amundsen and Antarctica in Cosgrove D and della Dora V eds High places: cultural geographies of mountains and ice I.B. Tauris, London 33-47

Yarwood R 2012 One moor night: emergencies, training and rural space Area 44 22-28

Yarwood R and Shaw J 2010 'N-gauging' geographies: craft consumption, indoor leisure and model railways Area 42 $425-33$ 